\title{
Sinergitas Sekolah dengan Pemerintah, Masyarakat dan Dunia-Dunia Usaha/ Industri: Sebuah Langkah Optimalisasi Pengelolaan Pendidikan Life Skill pada Siswa Disabilitas
}

\author{
School Synergy with Government, Community and Business/Industry: \\ An Optimization of Life Skill Educational Management for Students with \\ Disabilities
}

\author{
Eka Prihatin ${ }^{1}$, Imas Diana Aprilia ${ }^{2}$, Johar Permana ${ }^{3}$, dan Liah Siti Syarifah ${ }^{4}$ \\ 1,2,3 Sekolah Pascasarjana, Universitas Pendidikan Indonesia (UPI), Bandung, Indonesia \\ ${ }^{4}$ Prodi Manajemen Pendidikan Islam, STAI Syamsul 'Ulum, Sukabumi, Indonesia \\ ekaprihatin@upi.edu,imasdiana@upi.edu,permanajohar@upi.edu \\ liahss@staisyamsululum.ac.id
}

Naskah diterima tanggal 09/09/2019, direvisi akhir tanggal 10/12/2019, disetujui tanggal 16/12/2019

\begin{abstract}
Abstrak
Sinergitas sekolah dengan pemerintah, masyarakat dan dunia usaha/ industri menjadi salah satu kunci keberhasilan pengembangan life skill dalam mendorong kesempatan yang sama bagi siswa disabilitas di dunia kerja sehingga mereka bisa hidup mandiri di tengah keterbatasan yang dimiliki. Mengingat sumber daya yang dimiliki lembaga pendidikan sangat terbatas, maka sinergitas sekolah dengan berbagai pihak tersebut menjadi hal yang tidak bisa dipungkiri. Tujuan penelitian ini adalah untuk menganalisis manajemen kerjasama sekolah dalam melaksanakan pendidikan life skill pada siswa disabilitas. Jenis penelitian dan pengembangan (Research and Development) ini menggunakan siklus R\&D dari Borg \& Gall. Pengumpulan data dilakukan melalui studi dokumentasi, observasi dan wawancara mendalam kepada Kepala Sekolah Luar Biasa, perusahaan, dan orang tua siswa disabilitas. Validasi model dilakukan melalui Focus Group Discussion dengan melibatkan beberapa Sekolah Luar Biasa dan dunia usaha/industriyang ada di Kabupaten Subang serta pemerintah daerah setempat. Uji coba kelayakan model secara terbatas diberlakukan pada beberapa Sekolah Luar Biasa di Subang di antaranya yaitu SLB Waliwis Putih dan SLB Trituna. Hasil penelitian menunjukkan bahwa analisis sinergitas sekolah dengan pemerintah, dunia kerja dan masyarakat berkaitan dengan keterpaduan kurikulum sekolah dengan pendidikan life skill, pengelolaan pendidikan life skill pada siswa disabilitas, manajemen kerjasama sekolah, serta peran kepala sekolah dalam membangun kerjasama (sekolah) dengan pemerintah, dunia kerja dan masyarakat. Dari hasil penelitian dapat disimpulkan bahwa sinergitas sekolah, pemerintah, dunia kerja dan masyarakat akan berdampak optimal jika peran kepala sekolah memiliki kompetensi kewirausahaan yang mumpuni sehingga mampu memanfaatkan semua sumber daya yang ada berdasarkan cost benefit analysis yang tepat dalam mengelola pendidikan life skill untuk siswa disabilitas.
\end{abstract}

Kata Kunci: Kerjasama Sekolah, Pendidikan Life Skill, Siswa Disabilitas

\begin{abstract}
The synergy of schools with the government, community, and business/industry is one of the keys to the success of developing life skills in encourage equal opportunities for students with disabilities in the work so that they can live independently in their limitations. Considering that the resources of educational institutions are limited, the synergy of schools with various parties must be carried out. The purpose of this research was to analyze the management of school cooperation in implementing of life skill education for students with disabilities. This research
\end{abstract}


and development use the R\&D cycle of Borg \& Gall. Data collection was carried out through documentation studies, observations, and in-depth interviews with Principals of Special Schools, companies, and parents of students with disabilities. Model validation is carried out through Focus Group Discussion involving Schools, businesses/ industries in Subang, and the local government. Test the feasibility of the model limitedly was applied to Special Schools in Subang, including SLB Waliwis Putih and SLB Trituna. The results of the research showed that school synergy with the government, community, and business/industry was related to the integration of the school curriculum. With life skill education, life skill education management for students with disabilities, school cooperation management, and the role of a school principal in building cooperation (schools) with the government, society, and business/industry. Based on the results of the research can be concluded that the synergy of schools, government, community, and business/industry will have an optimal impact if the principal has entrepreneurial competence. In order, that be able to utilize all available resources based on the cost-benefit analysis appropriate in life skill education management for students with disabilities.

Keywords: Disability Students, Life Skill Education Management, School Cooperation

\section{PENDAHULUAN}

Berdasarkan Undang-Undang Nomor 8 Tahun 2016, penyandang disabilitas adalah setiap orang yang mengalami keterbatasan fisik, intelektual, mental, dan/atau sensorik dalam jangka waktu lama yang dalam berinteraksi dengan lingkungan dapat mengalami hambatan dan kesulitan untuk berpartisipasi secara penuh dan efektif dengan warga negara lainnya.Dengan demikian siswa disabilitas adalah siswa yang mengalami keterbatasan fisik, intelektual, mental dan/atau sensorik dalam jangka waktu lama sehingga mengalami hambatan dan kesulitas dalam berinteraksi sosial dengan masyarakat, dimana sebagian besar siswa menikmati pendidikan melalui jenis pendidikan khusus (Undang-Undang Nomor 2003 tentang Sistem Pendidikan Nasional) baik yang diselenggarakan secara inklusif atau berupa satuan pendidikan khusus pada tingkat pendidikan dasar dan menengah.

Sebagian besar penyandang disabilitas di berbagai negara termasuk di Indonesia masih mengalami kehidupan dalam kondisi rentan, terbelakang, dan/atau miskin disebabkan masih adanya pembatasan, hambatan, kesulitan, dan pengurangan atau penghilangan hak penyandang disabilitas sehingga orang tua, keluarga asuh dan pendidik menghadapi tantangan dalam pengasuhannya (Brown, 2007; Slayter \&
Springer, 2011). Dengan kondsi tersebut, kesamaan hak dan kesempatan bagi penyandang disabilitas menuju kehidupan yang sejahtera, mandiri, dan tanpa diskriminasi masih perlu penindaklanjutan dari peraturan perundang-undangan yang telah ada untuk dapat menjamin pelaksanaannya.Masalahmasalah di atas jangan sampai lebih parah seperti yang telah terjadi sebelumnya misalnya denganberakhir di jalanan, menjadi penganggur, terlibat dalam pekerjaan seksual, kriminalitas dan narkoba (Groce, 2003). Untuk mengantisipasi masalah tersebut di atas, pendidikan bagi siswa disabilitas diarahkan pada kemandirian.

Hak hidup secara mandiri dan dilibatkan dalam masyarakat untuk penyandang disabilitas meliputi hak: (1) Mobilitas pribadi dengan penyediaan alat bantu dan kemudahan untuk mendapatkan akses; (2) Mendapatkan kesempatan untuk hidup mandiri di tengah masyarakat; (3) Mendapatkan pelatihan dan pendampingan untuk hidup secara mandiri; (4) Menentukan sendiri atau memperoleh bantuan dari Pemerintah dan Pemerintah Daerah untuk menetapkan tempat tinggal dan/ atau pengasuhan keluarga atau keluarga pengganti; (5) Mendapatkan akses ke berbagai pelayanan, baik yang diberikan di dalam rumah, di tempat permukiman, maupun dalam masyarakat; dan (6) Mendapatkan 
akomodasi yang wajar untuk berperan serta dalam kehidupan bermasyarakat ( UndangUndang Nomor 8 Tahun 2016).

Kemandirian bagi siswa disabilitas dibentuk melalui pendidikan, pelatihan dan pendampingan yang dilakukan oleh sekolah untuk memiliki life skill yang sesuai dengan kebutuhan hidup(Permana \& Liah, 2018). Life skill merupakan kemampuan untuk perilaku adaptif dan positif, yang memungkinkan individu untuk melakukannya berurusan secara efektif dengan tuntutan dan tantangan kehidupan sehari-hari (Kawalekar, 2017; Murthy, 2016; Organization's, 2001; \&Singh, 2015) dan menjadi tugas sekolah untuk memberikan pendidikan life skill bagi siswa disabilitas sehingga ketika mereka lulus dari sekolah dapat memiliki kehidupan yang lebih baik dan memiliki kemandirian dalam kehidupannya.

Individu yang masih memiliki asumsi bahwa penyandang disabilitas menjadi beban bagi keluarga dan masyarakatdapat dipatahkan dengan konsep kemandirian ini (Aprilia \& Johar, 2019). Langkah yang harus dilakukan untuk kemandirian siswa disabilitas adalah kolaborasi antara sekolah, pemerintah, masyarakat dan dunia usaha/ industri. Di Indonesia, pemeritah mengeluarkan Undang-Undang Nomor 8 Tahun 2016 tentang Penyandang Disabilitas yang didalamnya dikemukakan bahwa Pemerintah, Pemerintah Daerah, Badan Usaha Milik Negara, dan Badan Usaha Milik Daerah wajib mempekerjakan paling sedikit 2 persen Penyandang Disabilitas dari jumlah pegawai atau pekerja, sedangkan perusahaan swasta wajib memperkerjaan sedikitnya 1 persen Penyandang Disabilitas dari jumlah pegawai atau pekerja. Undangundang tersebut menjadi dasar legal untuk mendorong kehidupan mandiri bagi lulusan siswa disabilitas.

Peluang di atas seharusnya mampu di tangkap dengan baik oleh sekolah dan kemudian dilakukan inovasi pembelajaran dengan membangun pendidikan life skill yang diblanded dengan mata pelajaran di Sekolah Luar Biasa (Apriliaet al., 2018). Tentu saja setiap Sekolah Luar Biasa (SLB) memandang peluang tersebut dengan beragam, tergantung dari visi dan misi sekolahnya. Disinilah kekuatan pemimpin dalam mengeksekusi dan menindaklanjuti peluang yang telah di buka oleh pemerintah. Kemampuan leadership dalam melaksanakan fungsi-fungsi manajemen dan kemampuan kewirausahaan dalam menetapkan sasaran kolaborasi menjadi keunggulan dan kunci keberhasilan bagi sekolah (Kuratko, 2007), sehingga pada akhirnya hal tersebut menjadi competitiveness bagi lulusan sekolah tersebut.

Mengingat pentingnya kerjasama antar institusi dalam upaya pengembangan life skill pada siswa disabilitas, artikel ini bertujuan untuk mengungkap sebuah model sinergitas sekolah, pemerintah,masyarakat dan dunia usaha/ industri sebagai sebuah langkah optimalisasi manajemen pendidikan life skill bagi siswa disabilitas di sekolah.

\section{METODOLOGI PENELITIAN}

Penelitian ini bersifat R\&D (research and development) karena fokusnya adalah mengembangkan model manajemen kerjasama sekolah dengan pemerintah, masyarakat dan dunia usaha/ industri secara sinergis bagi siswa disabilitas, dimulai dengan analisis manajemen kerjasama yang dilakukan selama ini oleh SLB yang berkaitan dengan pendidikan life skill. Hanya ada 4 fungsi manajemen yang paling sederhana dalam penelitian ini yaitu (1) Bagaimana perencanaan yang dilakukan oleh sekolah berkaitan dengan manajemen kerjasama untuk pelaksanaan pendidikan life skill; (2) Pengkoordinasian; hal ini merujuk pada langkah pengkoordinasian sekolah dalam pelaksanaan pendidikan life skill; (3) Pelaksanaan, ini adalah eksekusi perencanaan yang telah ditetapkan oleh sekolah untuk program pendidikan life skill dan (4) Evaluasi; dimana sekolah melihat ketercapaian tujuan dari pendidikan life skill itu sendiri.

Dengan menggunakan langkah dari Borg \& Gall (1983) yaitu desain penelitian yang digunakan untuk mengembangkan dan mengesahkan produk bidang pendidikan dengan langkah-langkah berikut: 


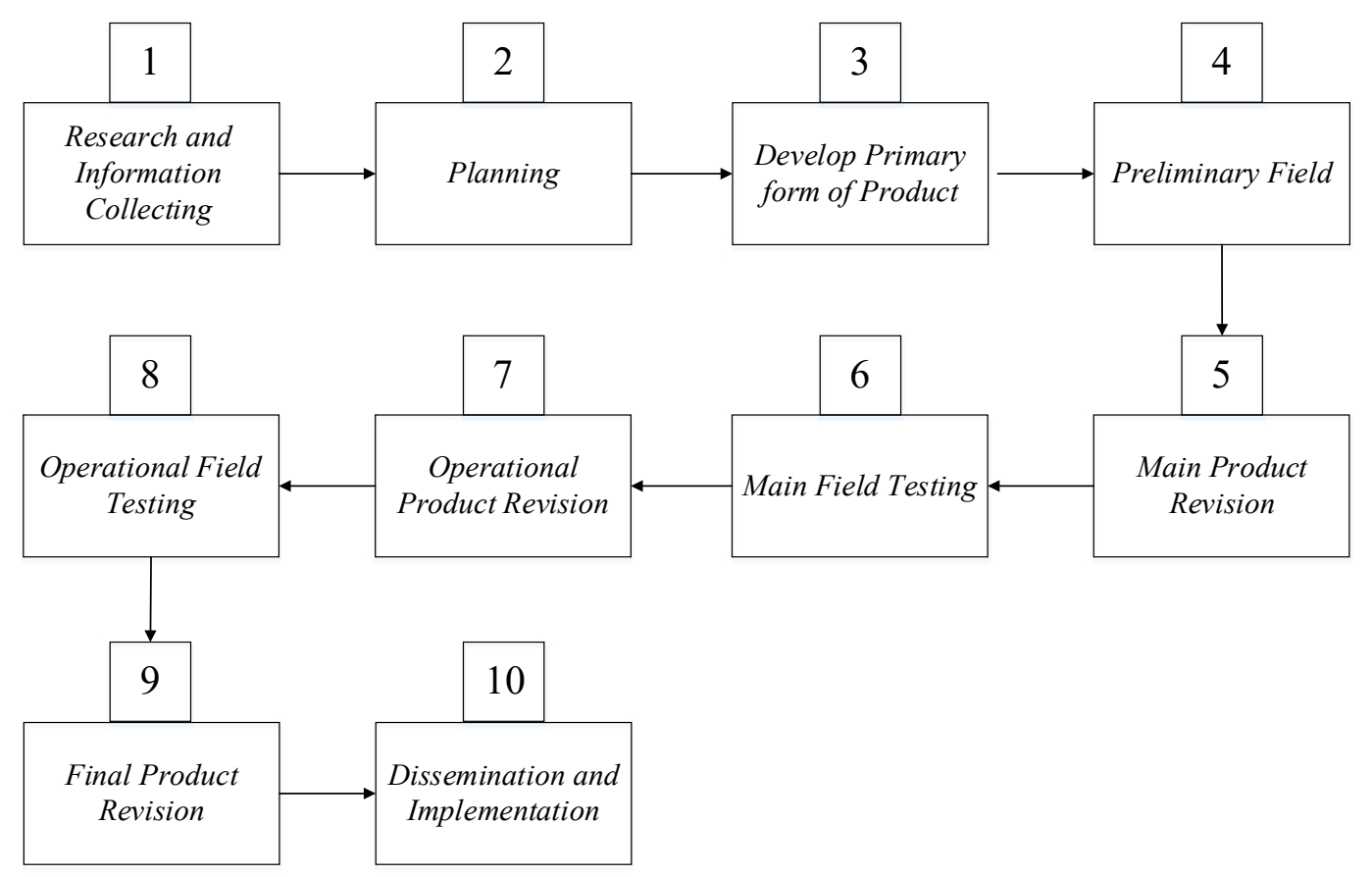

Gambar 1. siklus Educational research and development (Borg \& Gall, 1983)

Yang menjadi responden adalah SLBN Subang, SLB Waliwis Putih dan SLB Trituna, PT. Subang Autocomp Indonesia, Dinas Tenaga Kerja dan Transmigrasi, Dinas Pendidikan, dan pemilik home industry. Uji coba kelayakan model secara terbatas diberlakukan pada dua sekolah luar biasa di Subang yaitu SLB Waliwis Putih dan SLB Trituna.

\section{HASIL DAN PEMBAHASAN}

Analisis manajemen kerjasama sekolah dengan masyarakat dan DUDI memiliki fokus bahasan berkaitan dengan (1) keterpaduan kurikulum dengan pendidikan life skill; (2) manajemen pendidikan life skill; (3) sinergitas manajemen kerjasama sekolah dengan DUDI; (4) peran kepala sekolah dalam membangun kerjasama sekolah dengan DUDI, masyarakat dan pemerintah.

1. Keterpaduan kurikulum dengan pendidikan life skill.

Dalam hal ini karena pendidikan life skill sudah terintegrasi dengan kurikulum 2013, maka semua SLB telah melaksanakannya. Konsep life skill itu sebagaimana menurut sistem pendidikan menurut Ditjen Pendidikan Umum (Anwar, 2015) dikelompokan menjadi dua, yaitu: (1) General life skill yang mencakup personal skill dan social skill; (2) Spesific life skill mencakup academic skill dan vocational skill. Bagaimana penerapan pendidikan life skill pada siswa disabilitas? Hal tersebut dideskripsikan pada gambar berikut:

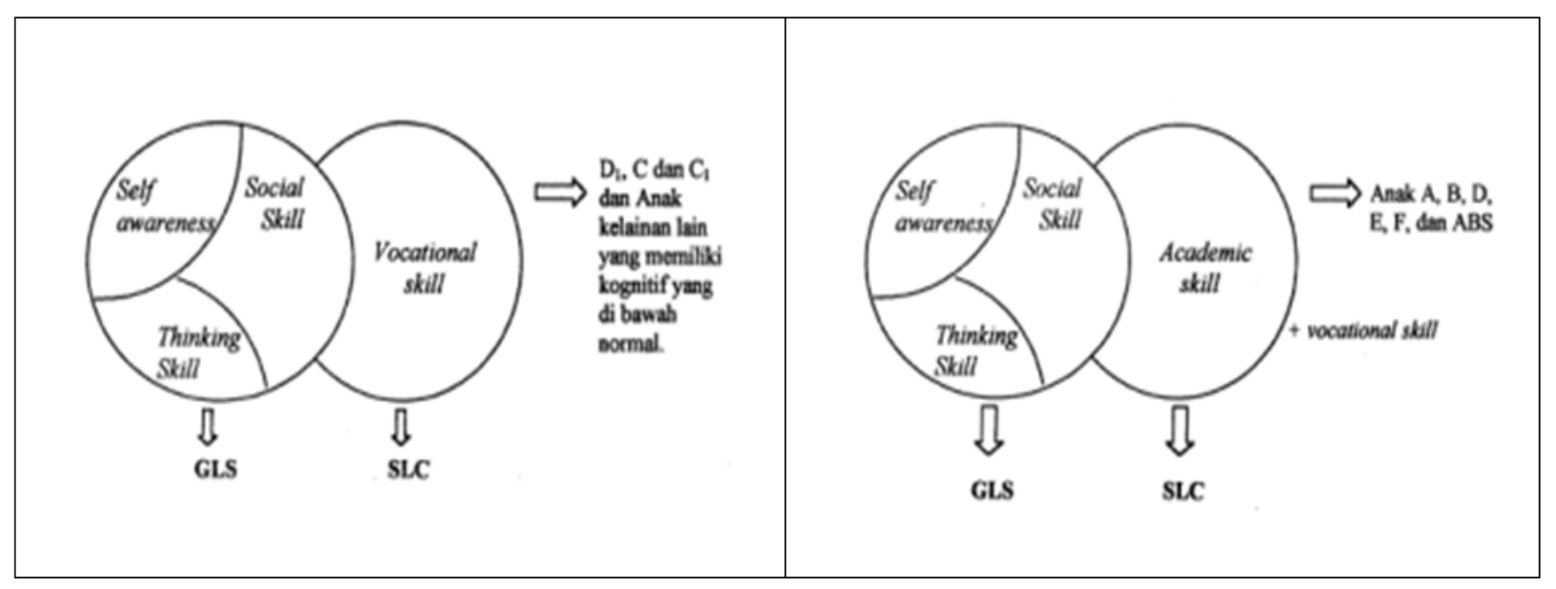

Gambar 2. Life Skill untuk Siswa Penyandang Disabilitas (Tim Suharsimi, 2002) 
Keterangan Gambar:

GLS: General Life Skill

SLC: Special Life Skill

A: Tunanetra

$\mathrm{B}$ : Tunarungu

C: Tunagrahita

$\mathrm{C}_{1}$ : Tunagrahita berat

D: Tunadaksa

$\mathrm{D}_{1}$ : Tunadaksa Berat

E: Tunalaras

F: Anak Berbakat

ABS: Anak Berkesulitan Belajar Spesifik

Life Skill adalah seperangkat keterampilan yang diperlukan untuk berhasil mengelola kehidupan sehari-hari (Mangrulkar et al., 2001). Berdasarkan gambar di atas, jenis kecakapan hidup yang cocok untuk dikembangkan untuk siswa disabel yang termasuk kategori tuna daksa berat, tuna grahita dan tuna grahita berat adalah kecakapan hidup umum dan kecakapan hidup kejuruan. Sedangkan bagi tuna netra, tuna rungu, tuna daksa, tuna laras, anak berbakat dan siswa berkesulitan belajar spesifik dapat dikembangkan juga jenis kecakapan akademik (selain kecakapan hidup umum dan kecakapan hidup kejuruan). Hal tersebut setidaknya menjadi gambaran awal tentang implementasi pendidikan life skill bagi siswa disabilitas berdasarkan jenis kecacatannya.

Hal lain yang peneliti tekankan adalah seperti diketahui bersama bahwa keberhasilan pelaksanaan pendidikan life skill tersebut sangat tergantung dari kreativitas dan inovasi dari tenaga pendidik, maka disinilah akan terlihat jelas keberhasilannya. Dengan kata lain, bagi guru SLB selain masalah pengetahuan, perspektif dan pendekatan yang mereka lakukan terhadap siswa-siswa disabilitas (King et al., 2014), guru dituntut kreatif dan inovatif di antaranya dalam membuat bahan ajar (Alfadillah, 2018) dan media pembelajaran (Kementerian Pendidikan dan Kebudayaan Republik Indonesia, 2019) yang mana hal ini manfaatnya besar sekali dalam perkembangan kemampuan siswa baik dalam meningkat kemampuan belajar, meningkat motivasi belajarnya dan sebagainya.
Sayangnya SLB hanya mengajarkan keterampilan hard skill yang dasar seperti tata boga, tata busana, tata rias, kesenian dan olah raga. Belum lagi masalah soft skill, kelayakan kerja (employability) dan kemampuan adapatasi (adaptability) merupakan beberapa di antara yang harus dipersiapkan siswa disabilitas dalam memasuki dunia kerja (Santos \& Rebeca, 2015). Kelayakan kerja (employability) dipahami sebagai kecenderungan aktif untuk adaptasi dan perubahan pribadi (Rothwell \& Arnold 2007), sedangkan kemampuan adapatasi (adaptability) berkaitan dengan perilaku adaptif, yang mengacu pada kemampuan orang tersebut untuk menyelesaikan permasalahan di dunia nyata (Greenspan, 2006). Jika dikaitkan dengan kecakapan hidup untuk kemandirian dasar, hal tersebut mungkin cukup, namun ada tantangan yang lebih menarik yang menjadi peluang lulusan dengan meraih dan memenuhi kuota $1 \%$ menjadi karyawan di perusahaan swasta atau memenuhi kuota $2 \%$ menjadi karyawan di perusahaan milik pemerintah (Undang-Undang Nomor 8 Tahun 2016), dan atau lebih luas lagi untuk memasuki DUDI. Maka keterampilan di atas tidak mencukupi, sehingga diperlukan upaya yang lebih keras lagi. Meskipun memang peluang usaha di perusahaan swasta maupun lembbaga pemerintah pun sampai saat ini harus masih dilakukan dengan jemput bola (Haryadi, 2019). Jika demikian adanya maka yang menjadi pertanyaan tantangan dan tugas siapa untuk mempersiapkan lulusan memasuki DUDI, apakah sekolah? Masyarakat? Pemerintah? Bahkan mungkin DUDI itu sendiri.

Barangkali disinilah bahan pengembang kurikulum untuk memadukan pendidikan kecakapan hidup yang dibutuhkan oleh DUDI dalam pendidikan di SLB, dan tentu saja keberhasilannya tergantung dari sekolah itu sendiri yaitu visi, misi dan tujuan serta gaya kepemimpinan dari kepala sekolah dan yang paling penting adalah kemampuan inovatif tenaga pendidik dalam mengemas materi ajarnya dengan mem-blended berbagai kebutuhan dan tuntutan serta harapan dari 
berbagai pihak dengan mata pelajaran yang ada. 2. Manajemen pendidikan life skill

Manajemen pendidikan life skill seperti dikemukakan di atas, bahwa setiap sekolah hampir seragam dalam menggunakan fungsi manajemen yang berkaitan dengan life skill yaitu perencanaan, pengorganisasian, pelaksanaan dan evaluasi (Robbins \& Marry, 2010). Empat fungsi manajemen tersebut dilaksanakan sesuai dengan guideline dari kurikulum 2013, sehingga hampir semua sekolah memiliki konsep yang sama dan hasil yang sama pula. Namun ada salah satu SLB yang menggunakan terobosan baru dengan mulai melakukan pendidikan life skill dengan terencana melibatkan SMA dan SMK, home industry, perusahaan (Tim Pengembang SLB Negeri Subang, 2018). Terobosan ini memiliki keberhasilan yang sangat bagus yang mendorong ketercapaian pendidikan life skill dengan kemadirian, serta mengantarkan lulusannya untuk menjadi karyawan perusahaan dan dunia usaha/ industri lainnya (Permana \& Liah, 2018).

Keberhasilan ini terjadi karena terobosan kesepakatan dengan dunia usaha/ industri yang berpijak pada Undang-undang yang mengemukakan bahwa perusahaan mengakomodasi penyandang disabilitas sekurangkurangnya satu persen dari angkatan kerja untuk sektor swasta dan dua persen untuk sektor publik (Undang-Undang Nomor 8 Tahun 2016). Meskipun Undang-undang tersebut sudah ada dan jelas dari tahun 2016, namun kenyataannya

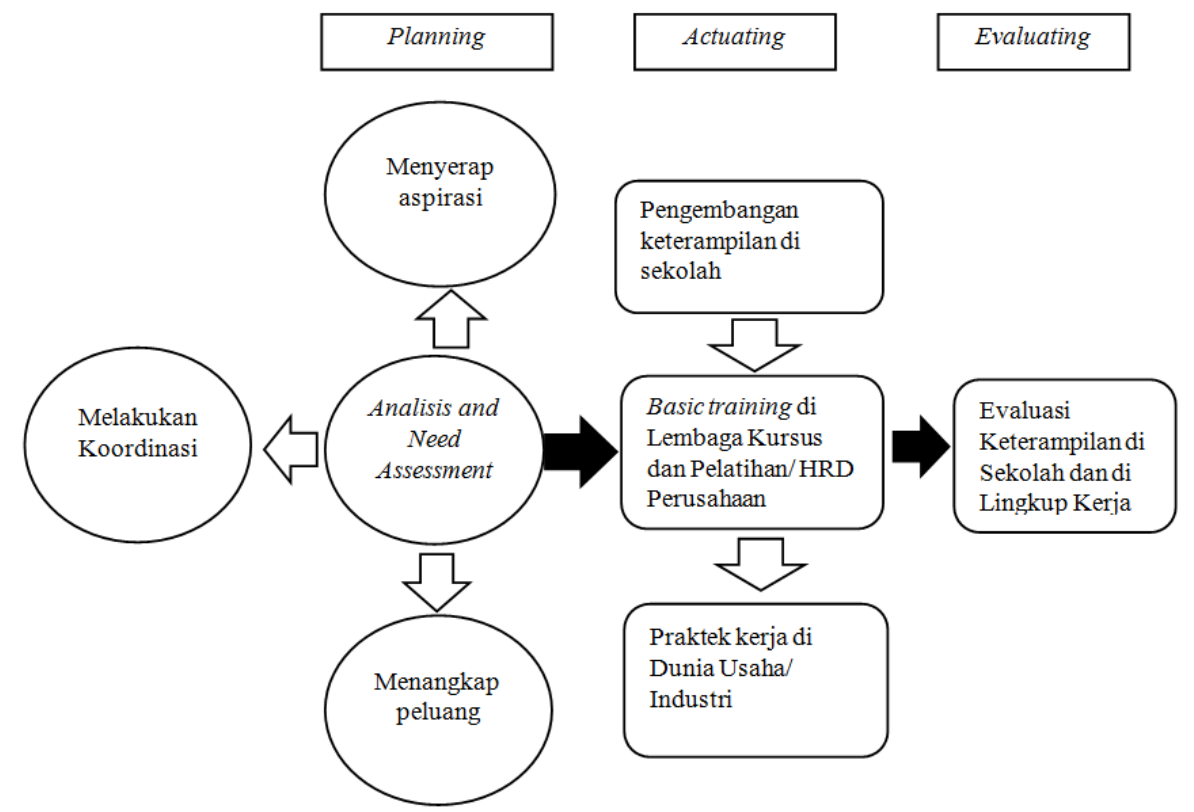

Gambar 3. Manajemen Model Pendidikan Life skill pada Siswa Disabilitas masih banyak perusahaan/ lembaga yang belum memfasilitasi dan menerima pekerja disabel serta masih minimnya jaminan perlindungan perusahaan untuk melindungi mereka (Mukti, 2019), sehingga dalam hal ini perlu peran pemerintah daerah untuk mengesahkan undang-undang di atas lebih tegas misalnya melalui peraturan daerah, dengan diikuti oleh sanksi (bagi perusahaan yang tidak mentaatinya) baik berupa denda cabut izin usahadan sebagainya.

Hanya saja jika dianalisis dari yang telah dijelaskan di poin pertama bahwa proses belajar mengajar hanya dikaitkan dengan tata boga, tata busana, tata rias, kesenian dan olahraga melalui program magang selama 3 bulan, sekilas dapat dinilai bahwa untuk siswa disabilitas keterampilan yang diterima selama magang jauh dari life skill yang mampu menghantarkan mereka dalam kemadirian ekonomi, sehingga perlu dikaji ulang. Model yang diajukan untuk pemecahan masalah ini adalah sebuah model manajemen pendidikan life skill yang nantinya dapat mencetak siswa disabilitas yang dapat bekerja dan diterima di masyarakat. Prihatin et al (2018) menemukan bahwa pendidikan life skill untuk siswa disabilitas dikelola melalui tiga tahap yaitu tahap perencanaan melalui analysis and need assessment, pelaksanaan melalui pengembangan ketrampilan hidup di sekolah, lembaga kursus/ pelatihan/ HRD perusahaan dan magang di dunia kerja (dunia usaha/ industri), terakhir adalah evaluasi ketrampilan kerja di sekolah dan dunia kerja. 
3. Kerjasama sekolah dengan pemerintah, dunia kerja dan masyarakat.

Dari semua sekolah yang menjadi responden, hanya satu sekolah yang memiliki manajemen kerjasama yang bagus, dimana sekolah tersebut melibatkan sekolah lain, home industry dan pemerintah dalam melaksanakan pendidikan life skill (Permanaet al., 2019). Disini peranan kepala sekolah dalam membangun sinergitas menjadi poin tersendiri untuk mencapai tujuannya, di mana inovasi dan keteguhan kepala sekolah dalam menjemput bola dan membuka setiap tantangan dan peluang serta menuntut keterlibatan semua pihak untuk membangun life skill siswanya membuahkan hasil yang gemilang.

Semua pihak ikut berperan dalam pembekalan life skill ini, sekolah menjalin kerjasama dengan pemerintah yang diwakili oleh Dinas Tenaga Kerja dan Transmigrasi dan Dinas Pendidikan, dari pihak DUDI diwakili oleh PT Subang Autocomp Indonesia dan Salon Fetty (home industry), serta komite sekolah sebagai wakil dari masyarakat (Focus Group Discussion, 19 November 2019). Pemerintah berpegang pada undangundang yang berlaku dimana Dinas Tenaga Kerja dan Transmigrasi membuka peluang sebesar-besarnya untuk menerapkan kuota 1 persen dan 2 persen karyawan disabilitas di dunia kerja. Dinas Pendidikan memfokuskan pada kualitas tenaga pendidikan, program pelatihan serta pendampingan bagi siswa disabilitas. Dan komite sekolah ikut ambil bagian dalam menyediakan tenaga lapangan yang ada di masyarakat untuk ikut berpartisipasi dalam pembangunan life skill anak sesuai dengan kemampuannya.

Memang sudah umum bahwa hubungan masyarakat dengan sekolah atau kerja sama stakeholder pendidikan mampu meningkatkan mutu pendidikan dan mempersiapkan serta mengantisipasi tantangan pendidikan saat ini (Majir, 2018). Menariknya sinergitas kerjasama yang telah dijelaskan sebelumnya menjadipemandangan yang harmonis dan menyejukkan karena hal tersebut telah membuka harapan yang luas bagi siswa disabilitas untuk memiliki life skill yang mampu memberikan benefit dan kemampuan ekomoni sehingga mampu mematahkan pandangan bahwa penyandang disabilitas menjadi beban, mereka mampu mengubah bahwa penyendang disabilitas mampu hidup setara dengan yang lainnya dengan memiliki marwah yang sama.

4. Peran kepala sekolah dalam membangun kerjasama sekolah dengan dunia usaha/ industri, masyarakat dan pemerintah.

Peran kepala sekolah terus berkembang seiring dengan ekspektasi sekolah, peserta didik, tenaga kependidikan, orang tua, pemerintah, dunia usaha/ industri dan masyarakat pada umumnya (Brandt, 2003; Habegger, 2008; Kemp, 2015; Mulford, 2003; Silvester Masuku, 2011) sehingga kemampuan kewirausahaan lebih menonjol dibanding dengan kemampuan lainnya. Dalam hal ini kepala sekolah harus mampu membaca peluang dan menjawab tantangan yang ada dengan mengandalkan kemampuan dan sumber daya yang dimiliki. Alfirevic et al (2018) dan Pepin \& Etienne (2019) menemukan bahwa orientasi kewirausahaan sekolah dan kepala sekolah dianggap sebagai deskriptor yang berguna dari perilaku individu dan kelembagaan dalam sistem pendidikan.

Pemimpin yang hebat adalah pemimpin yang mencapai tujuannnya dengan memanfaatkan sumber daya yang ada (Purwanto, 2009). Salah satu kepala sekolah yang menjadi responden memperlihatkan ciri kepala sekolah hebat yang mampu memanfaatkan sumber daya yang dimiliki, dimana ia mampu mendorong pemerintah untuk membuka peluang seperti yang diharapkan secara tegas, mengikut sertakan komite sebagai wakil masyarakat untuk ambil bagian dalam pendidikan life skill, menarik DUDI untuk ambil bagian dalam tanggungjawab mengembangkan pendidikan life skill, mendorong guru untuk mengoptimalkan kemampuannya berinovasi melalui pelatihan dari tenaga professional yang berkaitan dengan life skill yang selanjutnya di transfortasikan terhadap peserta didik (Permanaet al., 2018). Peran kepala sekolah yang demikian memiliki kualifikasi 
kewirausahaan yang mumpuni untuk ketercapaian tujuan pendidikan berkaitan dengan pendidikan life skill yang selanjutnya akan mengantarkan dan membuka peluang bagi lulusan untuk ikut serta menjadi bagian dari DUDI, sehingga memiliki nilai ekonomi yang baik dantidak kalah dengan masyarakat yang lainnya. Senergitas antara sekolah dengan pemerintah, DUDI dan masyarakat seperti ini dikemas dalam manajemen yang apik untuk menciptakan kerjasama yang berdampak positif. Secara sederhana konsep manajemen kerjasama itu adalah sebagai berikut:

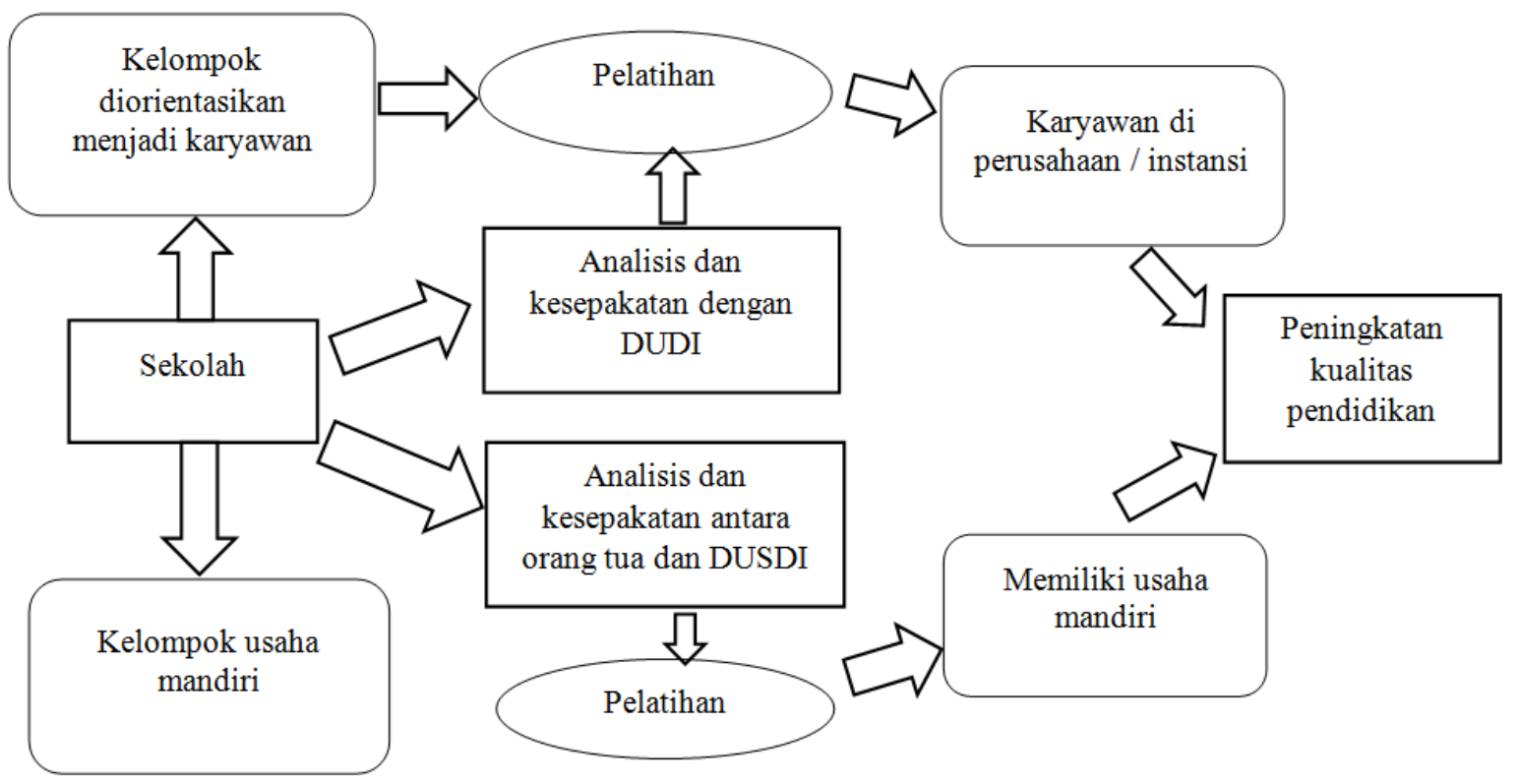

Gambar 4. Manajemen kerjasama sekolah

Gambar 4 mendeskripsikan sinergitas berbagai pihak dan perannya masing-masing dalam pengembangan life skill pada siswa disabilitas. Kerjasama sekolah yang bersinergi dengan pemerintah, masyarakat dan dunia kerja seharusnya diawali dengan analisis internal sekolah, dimulai dengan analisis peserta didik dengan batas pengembangannya (Prihatin et al., 2018). Hal tersebut dikarenakan siswa disabilitas sangat unik dibandingkan denga siswa lainnya yang mampu dilakukan pendidikan secara klasikal, siswa disabilitas dikelola secara eklusif dimana analisis dilakuan per peserta didik dimulai dengan pengelompokan kemampuan sampai dengan analisis kemampuan dan kebutuhan serta pelatihan yang disesuaikan dengan keadaan peserta didik tersebut. Sebut saja pengelompokkan peserta didik yang diorientasikan untuk menjadi karyawan dan peserta didik yang memilih untuk usaha mandiri. Yang diorientasikan menjadi karyawan adalah peserta didik tuna rungu dan tuna grahita ringan, sedangkan selebihnya didorong untuk usaha mandiri, namun pemilihan tersebut menjadi kesepakatan dengan orangtua/wali peserta didik.
Pendidikan life skill yang diberikan disesuaikan dengan perusahaan atau instansi yang akan di tuju, peran kepala sekolah adalah membuka peluang kesepakatan dengan DUDI tersebut. Jika perusahaan yang dituju merupakan perusahaan otomotif, maka tugas sekolah merinci apa bidang garapan yang bisa dimasuki, sehingga program pelatihan berkisar kemampuan tersebut, harapannya lulusan langsung bisa bekerja di perusahaan tersebut. Untuk peserta didik yang akan memiliki usaha mandiri, disini kepala sekolah memberikan keleluasaan orang tua/wali untuk memilih usaha apa yang ingin dilakukan, karena dalam program ini merupakan keterampilan kolaborasi antara anak dan orang tua untuk memulai usaha. Jika sudah ditentukan, maka sekolah mencari pelatih dan pendampingan dari tenaga profesional dari lingkungan masyarakat dan DUDI guna melatih duet ibu/bapak dan anak sehingga memiliki keterampilan yang akan membantu pembangunan ekonomi anak dan keluarga. Tugas pemerintah adalah membuka peluang, melakukan pelatihan dan pendampingan serta menyediakan dana hibah 
untuk memulai usaha mandiri tersebut. Jika konsep diatas dilakukan, maka penyandang disabilitas akan menjadi setara dalam ekonomi dengan masyarakat pada umumnya.

\section{KESIMPULAN}

Sinergitas sekolah, pemerintah, dunia usaha/ industri dan masyarakat akan memberikan dampak yang optimal jika peran kepala sekolah memiliki kompetensi kewirausahaan yang mumpuni sehingga mampu memanfaatkan semua sumber daya yang ada berdasarkan cost benefit analysis yang tepat dalam merancang pendidikan life skill untuk siswa disabilitas.

\section{DAFTAR PUSTAKA}

Alfadillah, N. (2018). Kadisdik: Siapkan Bahan Ajar yang Kreatif dan Inovatif. Diakses dari http://disdik.jabarprov. go.id/news/627/kadisdik\%3A-siapkan-bahan-ajar-yang-kreatif-dan-inovatif pada 30 Agustus 2019.

Alfirevic, N., Dijana, V., Jurica, P \& Sasa, P. (2018). Entrepreneurial Orientation of School Principals and Principalship in Croatia and Bosnia \& Herzegovina: Psychological, Educational and Social Perspectives. Diakses dari https://www.semanticscholar.org/paper/Entrepreneurial-Orientation-ofSchool-Principals-in-Alfirevic-Vican/c9a11498eca8d9b956db847f0cf208f2e55b4524 pada 30 Agustus 2019. author $=\left\{\right.$ Niksa Alfirevic and Dijana Vican and Jurica Ad $\{\mid v z\} i\left\{\backslash^{\prime} c\right\}$ Bojana Pavi $\{\mid v c\} i\left\{\mid{ }^{\prime} c\right\}$ and Sa $\{\mid v s\}$ a Petkovi $\{\backslash$ 'c $\}\}$, year $=\{2018\}\}$

Anwar. (2015). Pendidikan Kecakapan Hidup. Bandung: Alfabeta.

Aprilia, I, D., Johar, P \& Eka, P. (2018). Life Skill Educational Management Based on Vocational for Students with Disabilities to be Ready for Work. Telah dipresentasikan pada International Conference on Research of Educational Administration and Management (ICREAM 2018)

Aprilia, I. D \& Johar, P. (2019). Pemberdayaan Organisasi Kemasyarakatan melalui Usaha Ekonomi bagi Penyandang Disabilitas di Kabupaten Subang. Jakarta: Kementerian Riset, Teknomogi dan Pendidikan Tinggi Republik Indonesia.

Borg, W.R. and Gall, M.D. (1983). Educational Research: An Introduction. London: Longman, Inc.

Brown, J. (2007). Fostering children with disabilities: A concept map of parent needs. Children and Youth Services Review, 29, 1235-1248.

Brandt, D. E. (2003). The role of a school principal. Lethbridge, Alberta: University of Lethbridge Research Repository

Greenspan, S. (2006). Functional Concepts in Mental Retardation: Finding the Natural Essence of an Artificial Category.Exceptionality, 14 (4), 205-224

Groce, N. 2003. HIV/AIDS and People with Disability. The Lancet, 361:1401-1402.

Habegger, S. (2008). The Principal's Role in Successful Schools : Creating a Positive School Culture, (October), $42-46$.

Haryadi, Y. (2019, Juni 27). Personal interview.

Kawalekar, S. J. S. (2017). The Value of Life Skills in Higher Education. IOSR Journal of Research \& Method in Education (IOSR-JRME), 7(3), 43-46.

Kemp, A. (2015). Expectations and reality : Primary school principals' experiences of change leadership in the transition to digital learning environments.

Kementerian Pendidikan dan Kebudayaan Republik Indonesia. (2019). Guru Harus Kreatif dan Inovatif dalam Membuat Media Pembelajaran. Diakses dari https://gtk.kemdikbud.go.id/read-news/guru-harus-kreatifdan-inovatif-dalam-membuat-media-pembelajaran pada 30 Agustus 2019.

King, G., Amy, M., Shauna, K., Debra, S, Tanya, G. E., Jan, W. G., Kimberlea, J. G., Andrea, M., \& Ana, M. I. (2014). Residential immersive life skills programs for youth with disabilities: service providers' perceptions of experiential benefits and key program features. Disability and Rehabilitation: An International and Multidiciplinary Journal, Early Online, hlm. 1-10.

Kuratko, D. F. (2007). Entrepreneurial Leadership in the 21 st Century. Journal of Leadership and Organizational Studies, 2007, 13 (4), 1-11.

Majir, A. (2018). Rekonstruksi Hubungan Komite Sekolah Dan Sekolah Sebagai Upaya Meningkatkan Mutu Pendidikan. Jurnal Pendidikan dan Kebudayaan Missio, 10 (2), 137-273

Mangrulkar L, Whitman C, \&Posner P. (2001). Life skills approach to child and adolescent healthy 
human development. Washington, DC: Pan American Health Organization.

Masuku, S. (2011). The Instructional Leadership Role Of The High School Head In Creating a Culture of Teaching And Learning In Zimbabwe, (August).

Mukti, Y. F. (2019). Lika-liku Penyandang Disabilitas dalam Dunia Kerja Indonesia. Diakses dari https://www. kompasiana.com/himiespa/5ca9dc3e3ba7f715dd4e1562/lika-liku-penyandang-disabilitas-dalam-duniakerja-indonesia?page=all pada 30 Agustus 2019

Mulford, B. (2003). OECD Commissioned Paper School Leaders : Challenging Roles And Impact On Teacher And School Effectiveness, (April).

Murthy, P. C. G. V. (2016). Issues , Problems and Possibilities of Life Skills Education for School Going Adolescents, 3(3), 56-76.

Organization's, T. W. H. (2001). Skills for Health: Skills-based health education including life skills: An important component of a Child-Friendly/Health-Promoting School.Carmen Aldinger and Cheryl Vince Whitman, Health and Human Development Programmes (HHD) at Education Development Center, Inc.

Pepin, M \&Etienne, S. J. (2019). Assessing the impacts of school entrepreneurial initiatives. Journal of Small Business and Enterprise Development, 26 (2),273-288.

Permana, J., Eka, P \& Imas, D. (2018). Manajemen Pendidikan Life Skill berbasis Vokasional pada Siswa Disabilitas. Bandung: Sekolah Pascasarjana Universitas Pendidikan Indonesia.

Permana, J. Eka, P., Imas, D. A \& Liah, S. S. (2019). School Coperation Management in Implement of Life Skill Education for Disability Student. Telah Dipresentasikan di International Conference on Research of Educational Administration and Management 2019 pada 17 Juli 2019.

Permana, J \&Liah, S. S. (2018). Management of Internship For Special Schools. Telah dipresentasikan diIASTEM International Conference Kuala Lumpur, Malaysia 18-12-2018. Diakses dari https://worldresearchlibrary. org/proceeding.php?pid=2413 pada 10 Agustus 2019.

Prihatin, E..Imas, D. A \& Johar, P. (2018). Model Manajemen Pendidikan Life Skill pada Anak Berkebutuhan Khusus. Jurnal Penelitian Pendidikan, 18 (3), 306-317.

Purwanto, A. N. (2009). Optimalisasi Kinerja Kepala Sekolah. Makalah PPM Supervisi di Dinas Pendidikan Kecamatan Plered, halaman 1-5.

Robbins, S. P.,\& Mary, C. (2010). Manajemen Edisi Kesepuluh. Jakarta: penerbit Erlangga.

Rothwell, A.,\& J. Arnold. (2007). Self-perceived Employability: Development and Validation of a Scale. Personnel Review 36 (1), 23-41.

Santos, P. J. D. 1.,\& Rebeca, S. C. (2015): Workers with disabilities in sheltered employment centres: a training needs analysis. International Journal of Inclusive Education, 1464-5173.

Sekolah, Dinas Pendidikan, Dinas Ketenagakerjaan dan Dunia Usaha/ Industri. (2018, 24 Juli). Focus Group Discussion.

Singh, H. (2015). Strategies for Development of Life Skills and Global Competencies, (July).

Slayter, E., \& Springer, C. (2011). Child welfare-involved youth with intellectual disabilities: Pathways into and placements in foster care. Intellectual and Developmental Disabilities, 49, 1-13.

Tim Pengembang SLB Negeri Subang. (2018). Profil Sekolah Luar Biasa Negeri (SLBN) Subang. Subang: SLBN Subang.

Tim Suharsimi.(2002). Aspirasi Guru SLB terhadap Pelaksanaan Life Skill. Dinamika Pendidikan No 2/Tahun IX November 2002. 